\title{
SECURITY OF OBLIGATIONS AND RISKS IN CIVIL LAW OF RUSSIA THROUGH CENTURIES
}

\author{
Abstract \\ The article investigates by etymological and legal analysis the origin of the institution of obliga- \\ tions and risk management, for centuries in the process of formation of Russian law. \\ Key words: risk, obligations, unlawful actions, unprofitable consequences, force majeure, surety, \\ community, responsibility.

\section{References} \\ 1. Isachenko V.L., Isachenko V.V. Obyazatel'stva po dogovoram, Tom 1. Obshchaya chast'. \\ S.-Peterburg, 1914. \\ 2. Gins G.K. Sposoby obespecheniya obyazatel'stv (s tochki zreniya istorii i sistemy gra- \\ zhdaskogo prava)// ZHurnal Ministerstva yusticii, 1917, yanvar'. \\ 3. Istochniki prava i sud v drevnej Rossii: Opyty po istorii rus. grazhd. prava / [Soch.] \\ N. Dyuvernua. Moskva: Univ. tip., 1869. \\ 4. Udincev V.A. Istoriya zajma. Kiev, 1908. \\ 5. Pavlodskij E.A. Sluchaj i nepreodolimaya sila v grazhdanskom prave. M, YUrid. lit.,1978. \\ 6. Lubyagina D.V. Risk v grazhdanskom prave. Monografiya. Moskva: Prospekt, 2017.
}

\section{THE PERSPECTIVES AND LEGAL REGULATIONS OF CRYPTOCURRENCY: THE KAZAKHSTAN'S APPROACH}

\author{
Janadilov \\ Olzhas \\ the PhD, Candidate, Academy of Law Enforcement Agencies, \\ The Prosecutor General's Office of the Republic of Kazakhstan \\ (16, Republic str., Kosshi village, Tselinogradsky district, \\ Akmola region, Kazakhstan) \\ E-mail: kontakt789@mail.ru \\ Cheloukhine \\ Serguei \\ Ph.D., John Jay College of Criminal Justice, Department of Law \\ and Police Science \\ (524, West 59-th Street, New York, United States of America) \\ E-mail: scheloukhine@jjay.cuny.edu
}

\begin{abstract}
The core fundamentals for cryptocurrency legal regulations are objective processes associated to its growing role, which has a significant impact on the international financial system functioning. Today there is no clear scientific agreement as to a uniformly accepted "cryptocurrency" definition; this lack of agreement creates challenges in developing the mechanisms for the legal regulation of cryptocurrency and operations associated with it. The methodological basis of this study consists of the comparative law analysis, which includes the study of the most effective foreign approaches in the field of cryptocurrency legal regulation and electronic money, and applicability of foreign experience in the Republic of Kazakhstan.

Keyword: Cryptocurrency, Legal regulations, the international financial system, Bitcoin, Republic of Kazakhstan.

\section{INTRODUCTION}

With the rapid rise of crypto-currencies within the international financial system, there is a need for uniform legal regulation, based on objective standards.

Through the active expansion of global information and communication networks, the use of cryptocurrency has become common in many countries. Presently, the most common types of cryptocurrency are: Bitcoin, Ethereum, Litecoin, NEM and Ripple.
\end{abstract}


However, today there is no clear systematic agreement as to a uniformly accepted "cryptocurrency" definition; this lack of agreement creates challenges in developing the mechanisms for the legal regulation of cryptocurrency and operations associated with it.

In the modern digital world, crypto-currencies are an actively evolving phenomenon. Because there is no generally recognized definition of the term "crypto-currencies", there are certain complications with legal and currency regulation.

According to the official website of one of the most widely used crypto currency Bitcoin - cryptocurrency is designated as an innovative payment network and a new type of money that uses P2P technology, which functions without a central supervisory authority or bank. The transaction processing and emissions are collectively conducted through the network ${ }^{1}$.

Any form of currency that only exists digitally, that usually has no central issuing or regulating authority but instead uses a decentralized system to record transactions and manage the issuance of new units, and that relies on cryptography to prevent counterfeiting and fraudulent transactions ${ }^{2}$.

Vakhrushev D., for example, believes that "... the existing definitions of crypto-currencies do not fully disclose the essence of the analyzed phenomenon."

First, the existing definitions do not reflect the decentralized nature of the issuance of crypto-currencies. It is important to note that in the process of establishment of new payment devices, the computer capacities of millions of participants are involved. Data is taken from open electronic wallets, united in one peer-to-peer network where there is no central server, and each individual computer of this network serves as a server by itself. Therefore, all work together on keeping records of transactional history, which is distributed among all participants.

Second, crypto-currencies are codes encrypted with a special program at the owner's disposal, which is tracked and stored on electronic data storages (cloud) and is accepted as an instrument of payment by other users and organizations. From here it can be confirmed or argued that crypto-currencies are represented as a unique type or a system of electronic money. At first, it is essential to elucidate that electronic money in the broad sense is understood as monetary obligations of the issuer in the electronic form, which are stored on the electronic data storages (cloud) at the user's disposal. Moreover, these monetary obligations meet the following three criteria: they are recorded and stored on the electronic data storage; the monetary obligations are allotted by the issuer upon receiving money from other individuals in the amount of no less than the issued monetary value; and, monetary obligations are accepted as an instrument of payment by other (besides the issuer) organizations.

Third, in the case of crypto-currencies, the identification of the possessors and the retention of the fact of their alteration are based on the most modern cryptographic methods of protection, while the entire volume of information in the form of special blocks is stored on each server; whereas, the entire volume of information in the form of special blocks is stored on every server (computer, or member of the peer-to-peer network). It is considered impossible to hack, break or bypass this given protection system using the currently available hacking techniques" [1].

The dilemma of cryptocurrency legal regulation is escalated by the fact that the legality of Bitcoin and other crypto-currencies depend on the geographical location.

Some governments throughout the world attempt to cope with the possible risks and estimated remuneration or rewards of cryptocurrency by balancing consumers' protection, anticriminal activities and innovations.

The existing risks that governments throughout the world have may vary. Most of the developing markets either strongly oppose or use digital currencies such as Bitcoins, but in general, the economists use the regulatory principle of "soft touch" to strengthen innovation.

\footnotetext{
${ }^{1}$ Official site of the Bitcoin: [electronic resource]: access mode, URL: http:// bitcoin.org/

${ }^{2}$ Merriam-Webster. https://www.merriam-webster.com/dictionary/cryptocurrency
} 
Regulation - is a form of deception that consists of a wide variety of views of scientists and legislators and that in the absence of developed regulations, can lead to negative consequences.

Primary purpose of regulation is to insure the legitimacy of the payment for goods over the Internet. At present, Bitcoin has become a popular payment and investment tool, which is widely used to pay for goods, work, and services around the world. Also, currently the company "Bitcoiniacs" installed ATM machines in Canada that allows people to purchase this virtual currency. Paying with the Bitcoin can be done in various places, such as several cafeterias, fitness clubs and even for a company that develops a landscape design ${ }^{1}$.

\section{METHODOLOGY}

The methodological basis of the study consists of the comparative law, which includes the study of the most effective foreign approaches in the field of legal regulation of cryptocurrency and electronic money, and the applicability of foreign experience in the Republic of Kazakhstan.

The use of the comparative law method would allow a scientifically based assessment of the compliance of the current legislation and the existing practice in the Republic of Kazakhstan in the field of legal regulations of cryptocurrency and electronic money.

Accordingly, by recognizing the existing conflicts or contradictions, a scientific basis can be created for the modernization of existing legal institutions and the creation of uniform international standards.

\section{FINDINGS}

Accordingly, the initial task is to determine whether a cryptocurrency is money or not ${ }^{2}$. The formulation of a scientific problem concerning the norms of law in the Republic of Kazakhstan, which is used to regulate cryptocurrency, its turnover and operations with the use of cryptocurrency, is due to the level of development of global information communication networks and digital technologies. Furthermore, the presentation of this scientific problem is due to the fact that there is a need for a new approach to the scientific characteristics of virtual money and money surrogates.

It is important to note that the development of information and communication networks, as well as institutional and economic factors, is of great importance for the development of cryptocurrency. That is how, the technological capabilities of modern information technology and computer systems have reached high indicators. The modern information technology innovations not only affect the nature of the financial markets' functions, but also on all reproduction processes [2], while not only contributing to the acceleration of the dynamics of economic change, but also a new factor in the immanent instability of economic systems [3].

Moreover, the emergence of the possibility of remotely combining computers into one network, which is understood as the Internet for solving specific problems, has become the basic premise of the emergence of a new type of payment instrument with a modern security system. Therefore, due to the constant advancement of digital technologies and scientific technological progress allowed creating the most convenient and cheap payment instrument that can meet the needs of the modern society, particularly the interests of issuers, intermediaries and other users.

However, considering the lack of a full-fledged legal regulation of cryptocurrency turnover and operations carried out through cryptocurrency, it creates both difficulties and danger of cases of legalization of money (laundering) and other property obtained by criminal means with a help of cryptocurrency.

At present time, there is no single definition of the term cryptocurrency as well as relatively there are no rules and regulations governing their turnover or operations, since this process is only at the stage of formation and development, both at the inter-national and national levels.

\footnotetext{
${ }^{1}$ See for example http://www.bitcoiniacs.com/

2 How legal is Bitcoin and Crypto Currencies? // Analytical portal "CryptoCompare" / https://www.cryptocompare.com/coins/guides/how-legal-is-bitcoin-and-crypto-currencies/
} 
Further, considering it proper to highlight the legal nature of cryptocurrency in the Republic of Kazakhstan.

According to pages 127 and 128-1 ГК (Civil Code CV) PK (Republic of Kazakhstan RK) cryptocurrency does not appear to be a recognized as money (currency), and does not act as a financial tool, since it does not meet the criteria set out in the current Civil Code of the Republic of Kazakhstan.

According to the Republic of Kazakhstan's Laws, paragraph 2 page 1, of June 13, 2005 No. 57 "currency regulation and currency control" states that "currency - is a monetary units accepted by countries as legal payment instrument, or official standards of value in cash and non-cash forms, in the form of banknotes, treasury notes and coins, including precious metals (including those withdrawn or withdrawn from circulation but subject to exchange for banknotes in circulation), as well as funds in ac-counts, including in international monetary or settlement units"2.

According to the same law of June 13, 2005 No.57, “...foreign currency - the currency of a foreign state, as well as international monetary or accounting units," by which we can understand currency notes (token money) expressed in the form of bank-notes, treasury notes, coins that are in circulation and are legal means of cash on the territory of one or another foreign state or several foreign states, as well as withdrawn or withdrawn from circulation, but are subject to exchange by specified currency notes or signs" 3 .

Considering that cryptocurrency, Bitcoin in particular, does not fall within the specified criteria for money and / or currency, including a foreign state or group of states; thus people cannot deposit or place it on the account of any credit organization in the Republic of Kazakhstan.

Discussing the possibility of applying to transactions that are carried out using virtual currencies that are not supported by generally accepted currency notes, it is important to note that in accordance with page 38 of the Republic of Kazakhstan's Laws, dated March 30th, 1995 No. 2155 "Regarding the National Bank of the Republic of Kazakhstan": "Monetary unit (national currency) of the Republic of Kazakhstan is Kazakhstan tenge. Kazakhstan tenge consists of 100 tiyn," wherein, considering that the currency in circulation of the Republic of Kazakhstan consists of banknotes and coins. The structure of banknotes and coins is determined by the National Bank of Kazakhstan."

In that regard, it becomes obvious that the introduction of other monetary units on the Republic of Kazakhstan's territory, the determination of the structure of the de-nominations falls within the competence of the National Bank of the Republic of Kazakhstan, respectively, the release of cash surrogates is prohibited.

At present, people in Kazakhstan are beginning to store their investments in cryptocurrency. Neither political nor economic changes in the world directly affect its course. That is why more and more residents prefer to transfer physical money into virtual. Some people even claim that they were able to earn a good profit by transfer-ring into virtual currency. However, experts caution: that electronic currency is very unreliable. Money on the Internet is not protected, and people are at risk of losing everything, all at once. The National Bank of the Republic of Kazakhstan addressed similar precautions ${ }^{5}$.

Furthermore, the economist A. Arupov, director of the Institute of World Economy and International Relations wrote: "it is not guaranteed that tomorrow these ten thousand bitcoins

\footnotetext{
${ }^{1}$ Grazhdanskyi kodeks RespublikiKazakhstan, 27. 1994. V redaktsii Zakona Respubliki Kazakhstan 27 fevralya 2017. № 311-V. Vedomosti Verkhovnogo Soveta Respubliki Kazakhstan. 1990. № 23-24; 1995 № 15-16, statya 109; № 20. Statya 121.

2 Zakon Respubliki Kazakhstan 2005. № 57 «O Valutnom regulirovanoo I valyutnom kontrole». V redaktsii Zakona RK. 16.05.2014 № 203-V. Vedomosti Parlamenta Respubliki Kazakhstan, 2005. N 11, statya 38.

${ }^{3}$ Ibid.

4 Zakon Respubliki Kazakhstan 30.03.1995, № 2155 «O Natsionalnom Banke Respubliki Kazakhstan». V redaktsii Zakona RK. 14.01.2016 № 445-V. Vedomosti Verkhovnogo Soveta RK

5Ibid, 1995 г., N 3-4, staya.23, N 12, statya 88, N 15-16, statya 100, N 23, statya. 141.

https://www.ktk.kz/ru/news/video/2017/03/06/76649
} 
will be suitable for something. Why? Because Bitcoin is a conditional digital virtual (I would not ad-dress to it as physical money) unit, recognized by the members of this community, that do not possess any gold collateral or material assets." "Cryptocurrency is not tied to the official monetary unit or any other assets as well as the corresponding security and legally responsible entities for operations with their service... Participants who contributed money to these organizations do not have legal guarantees for the return of the invested money..."1.

By analyzing the mechanism of operations and circulations of crypto-currencies, it is logical to understand a distinct type of electronic money as a "cryptocurrency", which functions on a decentralized emission (issuance) mechanism and circulation and constitute a complex system of information technology procedures based on cryptographic methods of protection.

Transactions of cryptocurrency are currently based on the informal norms of the participants in this process. At present time, there are no single models formed and rules for the treatment of cryptocurrency. This process is still developing. Thus, currently, the order of payments between participants of financial processes with handling of cryptocurrencies, the order of their registration, accounting of transactions, and taxation issues are not determined. Today, all operations are traced, but those operations are non-existing in nature, i.e. It is impossible to identify the parties to the payment transaction, if the last have not done so. All of this can negatively affect the stage of development and growth of this payment instrument; moreover, it can become a way of fraud and making illegal payments.

In addition, cryptocurrency causes a lot of controversy around the world. For instance, the director of the world economy and international relations institute A. Arupov indicates that "in Japan, Bitcoins have already been legalized. In Thailand, they are prohibited, and in Bangladesh for the possession of virtual money is punishable by incarceration" [4]. In Kazakhstan, currently there is no written law that would regulate the production and circulation of cryptocurrency.

of particular interest is the legal regulation of cryptocurrency's circulation in some foreign countries.

Consequently, for the first time Bitcoin was banned in Thailand at the end of July 2013. Nowadays, buying and selling and transferring "bitcoins" as well as virtual currency payments for goods and services are considered illegal in Thailand [5].

The People's Bank of China also prohibited their financial and payment institutions from conducting any bitcoin operations. According to the recommendations dated December 5, 2013, Bitcoin does not have the status of legal payment instrument or a currency that must be received as a payment. The People's Bank of China characterizes Bitcoin as a virtual commodity [6].

According to Savchenko L.M., Yuzaeva A.G., and Afanasyeva T.N., "...in 2013, the German Ministry of Finance made a statement that Bitcoin could not be classified as electronic or foreign currency, but rather the definition of private money by which multilateral clearing (finance) operations can be carried out"[7] .

In varying degrees, Bitcoins are allowed to be used in Japan, Switzerland, Singapore, Bulgaria and other countries but consider it necessary to regulate their use and taxation.

Accordingly, in early January 2014, it became known that the tax authorities of Singapore equated operations with Bitcoin as transactions subject to tax [8]. The average income tax is planned to be collected from companies engaged in the purchase and sale of Bitcoins. Longterm investments in Bitcoins, which are equivalent to investments in capital, will not be taxed. When exchanging Bitcoin for real goods and services, a tax of $7 \%$ will be collected on goods and services (for non-residents, a tax on goods and services does not occur).

The tax on goods and services will not be subject to the acquisition of virtual goods and services for Bitcoins, such as in-app purchases. On March 13, 2014, the Monetary Authority of Singapore announced its intention to regulate the activities of intermediaries engaged in operations with virtual currencies, meaning, among them, including Bitcoin [9; 10]. Such intermediaries who exchange virtual currencies for physical or real will be obliged to identify their custom-

${ }_{1}$ «apital Tsentr delovoi informatsii. https://kapital.kz/expert/akimzhan-arupov/ 
ers and report suspicious transactions to the appropriate office. In general, the same requirements will be imposed on intermediaries as enterprises engaged in the exchange of real currencies, as well as the provision of remittances. The purpose of these measures is to minimize the risks associated with money laundering and terrorist financing arising from the anonymous nature of virtual currencies.

The National Bank of Croatia believes that Bitcoin is legal in Croatia, but it should not be considered as electronic money, although it has some similarities with electronic money. Cryptocurrencies can be legally used in the country, although they cannot be considered as a legal way of payment and that is, sellers are not obliged to accept them in Croatia on a level with local currency ${ }^{1}$.

In the U.S. Bitcoin is considered a "virtual currency" and is also considered necessary to regulate it properly. On March 25, 2014, the U.S. Internal Revenue Service issued a guide on taxing transactions with Bitcoins and other virtual currencies [11].

In July 2017, the U.S. Securities and Exchange Commission decided to equate ICO Initial coin offering, (from English - "initial offer of coins, initial placement of coins") to securities. Companies that do not register the release of cryptocurrency or ICO will be punished [12; 13].

ICO means offering or placing coins, the so-called tokens, with the subsequent sale of a new cryptocurrency to investors. Now such operations will need to register accordingly. Most often, this type of fundraising is used by startups working in the technological field 2 .

According to p.p. 29, 31 of the Guidelines on the Application of the Risk-Based Approach "Virtual Currencies" in the current Recommendations No. 2 of the FATF (intergovernmental organization - Financial Action Task Force on Money Laundering) set requirements for interaction and cooperation at the national level in order to implement policies aimed at countering money laundering and terrorist financing, including in the virtual currency sector. Other countries may consider creating structures, such as inter-agency working groups that interact with each other in order to develop and implement effective policies, regulations, and other measures aimed at identifying and reducing the risks associated with virtual currency.

If virtual currency has become a significant element of the financial sector, countries should consider the feasibility of analyzing the relationship between regulation and supervision of activities related to virtual currencies. In this regard, countries are encouraged to consider the possibility of conducting political work in the short and long term to develop a comprehensive system for regulating products and services based on virtual currency ${ }^{3}$.

The President of the Republic of Kazakhstan, Nursultan Nazarbayev, at the 10th Astana Economic Forum in June 2017 expressed the following opinion: "There is a need to transform the global financial architecture, which I had to talk about from this stage. The time has come to seriously consider the introduction of an international payment unit. It will save the world from currency wars, speculation, evade distortions in trade relations, reduce market volatility. A currency should have a simple, transparent emission (money circulation) mechanism, subject to its consumers. Considering digitalization, the development of technologies such as blockchain, such a unit of ac-count can be created in the form of cryptocurrency"4.

In this regard, it is believed that there are both positive and negative opinions and positions regarding cryptocurrency. However, we cannot deny the fact of its existence. Therefore, there is a real need for its legal regulation. The formulation of this problem requires its prompt solution.

\section{CONCLUSION}

In retrospect, hereby the government bodies of different countries have different approaches to regulate the issue of determining the legal status of virtual currencies, as well as the

\footnotetext{
${ }^{1}$ https://ru.wikipedia.org/wiki/ Bitkoin, accessed 21.02.2015

${ }^{2}$ https://rg.ru/2017/07/27/kriptovaliutu-v-ssha-priravniali-k-cennym-bumagam.html

${ }^{3}$ http://www.fatf-gafi.org/media/fatf/documents/reports/Guidance-RBA-Virtual-Currencies.pdf

${ }^{4}$ https://tengrinews.kz/kazakhstan_news/nazarbaev-predlojil-sozdat-mejdunarodnuyu-kriptovalyutu-320433/
} 
possibility of performing operations in crypto-currencies on the territory of aforementioned countries. At the same time, public relations that are emerging regarding the use of cryptocurrencies continue to evolve and embrace the whole world. In this regard, there is a reasonable need to study existing public relations and identifying trends in the regulation of virtual currencies, as well as the creation of a new mechanism for legal regulation of this global innovation.

In addition, at present virtual currencies, such as Bitcoin, cannot be provided for the fulfillment of monetary obligations of a person who provides money to third parties and for whom the person who provided the money has the right to transfer orders exclusively using electronic means payment, since virtual currency is not legal tender on the territory of the Republic of Kazakhstan.

The virtual nature of cryptocurrencies, bitcoin in particular, that do not have the material base, decentralized nature of cryptocurrency emissions, the lack of security, and the volatility of the bitcoin's rate, do not suggest high liquidity of virtual currencies, as well as considering cryptocurrencies, in particular bitcoin, as a universal equivalent of the value of goods and services. Additionally, the mechanism for issuing and storing data of Bitcoins, as well as the lack of identification of users and the lack of ability to monitor transactions, create conditions for abuse by individuals and legal entities, including operations aimed at legalizing (laundering) income received by criminal means, and the financing of terrorism, through the use of virtual currencies. At the same time, the demand for the purchase of goods, payment for work and services, as well as the implementation of transfers using Bitcoin has a number of advantages due to the innovative financial and technological component of crypto-currencies.

Virtual currencies are outside the legal spectrum and the implementation of transactions and transactions using cryptocurrencies, in particular Bitcoin, on the territory of the Republic of Kazakhstan may have negative consequences for the persons performing such operations.

With that, the widespread use of Bitcoin as a means of payment or an analogue of "foreign currency" in other countries orders the need to give cryptocurrencies a certain legal status, identify their legal nature, create a mechanism for regulating operations and transactions made using cryptocurrencies, making the maximum possible identification of participants operations with the use of cryptocurrency, as well as the implementation of control, and supervision over the activities of entities creating and using such crypto-currencies currency.

Based on the aforementioned, this paper proposes to convene an international conference on the development and adoption of the manuscript of international convention that would regulate relations on the use and circulation of cryptocurrency. The rules of this convention must put an end to the question of the recognition or non-recognition of cryptocurrency as a legal tender. To frame a clear mechanism for its turnover, it is important to provide mechanisms for bringing to justice individuals for illegal operations with it.

The security of transactions using cryptocurrency should be provided by a supranational structure. For example, it would be effective to create an authorized inter-national one that would exist isolated from existing international financial institutions. We believe that it is a new, independently functioning international organization that would be able to contribute more effectively to the development of cryptocurrency.

\section{References}

1. Vakhrushev D., Zhelezov O. Kriptovalyuta kak fenomen v sovremennoi informatsionnoi ekonomiki: problem teoreticheskogo osmyslenia. Internet zhurnal "Maukovedenie" https://naukovedenie.ru/PDF/127EVN514.pdf

2. Alekseeva $N$. Razvertyvanie I sovershenstvovanie vosproizvodstvennykh tsepochek v resultate vozdeistviya intellektualnogo kapitala malogo bisnesa. Mnogourovnevoe obschestvennoe vosproizvorstvo. 2010. № 1.7 - 11.

3. Vakhrushev D. Samoorganizatsiya I dinamicheskaya ustoichivost ekonomicheskih system. Avtoreferat dissertatii doktora ekonomicheskih nauk. Kostroma. Gosudarstvennyi universitet. 2004. P. 48. 
4. Arupov A. Spetsialisty predosteregayut kazakhstantsev, khranyaschikh dengi v kriptovalute. «Zakon.kz» https://www.zakon.kz/4847559-specialisty-predosteregajut.html

5. Clinch M. Bitcoin banned in Thailand // A Division of NBC Universal https://www.cnbc.com/id/100923551

6. Ankit Panda. People's Bank of China Issues a Regulatory Notice on Bitcoin / The diplomat https://thediplomat.com/2013/12/peoples-bank-of-china-issues-a-regulatorynotice-on-bitcoin/

7. Savchenko L., Yuzaeva A., Afanasieva T. Virtualnaya valuta Bitcoin. Keberleninka. https://cyberleninka.ru/article/n/virtualnaya-valyuta-bitcoin

8. Moskowitz D. Singapore Tax Authorities (IRAS) Recognize Bitcoin and Gives Guidance // Coin republic http://coinrepublic.com/singapore-tax-authorities-iras-recognize-bitcoinand-gives-guidance

9. Khan V. Singapur ureguliroval nalogooblizhenie operatsii Bitcoin. «Zakon.ru» https://zakon.ru/blog/2014/1/12/singapur_ureguliroval_nalogooblozhenie_operacij_s_ bitcoin

10. Kuznetsov $V$., Yakubov A. O podkhodakh v mezhdunarodnom regulirovanii kriptovalut (Bitcoin) $\mathrm{v}$ otdelnykh inostrannykh yurisdiktsiyah

11. Smolyakov S. «Zolotaya» Oplata truda ksk novyi sposob zaranotnoy platy v sovremennoi Rossiiskoi ekonomike. Vestnik Yugorskogo gosudarstvennogo universiteta. 2015. № S32 (38). Pp. 105 - 107.

12. Kazanovski P. V SSHA priravnyali blokchain ICO k vypusky obychnykh akstii. https://www.rbc.ru/finances/26/07/2017/5978309f9a7947ab4451167d.

13. Clayton J. Testimony on "Virtual Currencies: The Oversight Role of the U.S. Securities and Exchange Commission and the U.S. Commodity Futures Trading Commission. February 6, 2018. https://www.banking.senate.gov/imo/media/doc/Clayton\%20Testimony\%2026-18.pdf

\section{ПЕРСПЕКТИВЫ И ПРАВОВЫЕ ПОЛОЖЕНИЯ \\ КРИПТОВАЛЮТЫ: ПОДХОД КАЗАХСТАНА}

Жанадилов Олхаз, кандидат юридических наук, Академия правоохранительных органов при Генпрокуратуре Республики Казахстан (Казахстан, Акмолинская область, Целиноградский район, пос. Косшы, ул. Республики, 16).

E-mail: kontakt789@mail.ru

Шелухин Сергей, доктор права, университетский профессор факультета законодательства, полиции и криминальной юстиции, Городской Университет (Соединенные Штаты Америки, Нью-Йорк, 59-я Вест-Стрит, 524).

E-mail: scheloukhine@jjay.cuny.edu

\section{Аннотация}

Основными принципами правового регулирования криптовалюты являются объективные процессы, связанные с ее растущей ролью, что оказывает существенное влияние на функционирование международной финансовой системы. Сегодня нет четкого научного согласия относительно единообразно принятого определения "криптовалюты"; это отсутствие согласия создает проблемы в развитии механизмов правового регулирования криптовалюты и операций, связанных с ней. Методологическую основу данного исследования составляет анализ сравнительного правоведения, включающий изучение наиболее эффективных зарубежных подходов в области правового регулирования криптовалюты и электронных денег, а также применимость зарубежного опыта в Республике Казахстан.

Ключевые слова: криптовалюта, законодательство, биткоин, Республика Казахстан. 